\title{
PELAJARAN BAHASA INDONESIA PESERTA DIDIK KELAS XI SMK GARUDA NUSANTARA, DEMAK
}

\author{
INDONESIAN STUDENTS STUDY CLASS XI SMK Garuda Nusantara, DEMAK
}

\author{
Rati Riana dan Sofyandanu Setiadi \\ Universitas Semarang
}

\begin{abstract}
ABSTRAK
Keterampilan berbicara merupakan salah satu keterampilan yang dibutuhkan dalam pendidikan. Badan Penelitian dan Pengembangan Kemendikbud (2011) mengungkapkan bahwa nilai rata-rata UN pada pelajaran bahasa Indonesia untuk sekolah menengah atas dan sederajat terendah, yaitu sebesar 7,12. Sementara itu, nilai bahasa Inggris 7,52, Matematika 7,30, dan IPA 7,41. Untuk meningkatkan proses pembelajaran diperlukan model penelitian baru, antara lain Think Pair Share dalam pembelajaran membaca. Tahap-tahap dalam pembelajaran Think Pair Share adalah thinking (berpikir), pairing (berpasangan), dan sharing (berbagi). Penelitian ini bertujuan untuk mengetahui peningkatan kemampuan bericara pada peserta didik. Subjek penelitian adalah peserta didik kelas XI SMK Garuda Nusantara tahun ajaran 2014/2015. Data dalam penelitian ini dianalisis secara kualitatif dan kuantitatif. Pengambilan data dilakukan dengan metode tes, observasi, angket, wawancara, dan dokumentasi. Desain penelitian ini terdiri 2 siklus. Setiap siklus terdapat empat tahap yaitu perencanaan, pelaksanaan, pengamatan, dan refleksi. Hasil refleksi dijadikan dasar untuk menentukan keputusan perbaikan pada siklus berikutnya. Hasil penelitian menunjukkan bahwa pada prasiklus, dari 37 peserta didik yang mengikuti pembelajaran, memperoleh nilai 70 ke atas hanya 8 orang $(21,62 \%)$. Sementara itu, pada siklus I terjadi peningkatan yang signifikan, yaitu sebanyak 25 orang $(55,56 \%)$. Jadi, kenaikannya sebesar $33,94 \%$. Setelah diadakan perbaikan siklus II, peserta didik yang memperoleh nilai di atas 70 sebanyak 42 orang $(93,33 \%)$, sedangkan yang belum tuntas 3 orang $(06,67 \%)$. Hasil siklus II ini telah mencapai KKM dan memenuhi standar ketuntasan sebesar $75 \%$. Berdasarkan hasil penelitian disimpulkan bahwa penerapan model pembelajaran kooperatif teknik Think Pair Share dapat meningkatan kemampuan berbicara peserta didik pada mata pelajaran bahasa Indonesia.
\end{abstract}

Kata Kunci: Pembelajaran Kooperatif, Teknik Think Pair Share (TPS), Keterampilan Berbicara, pada Mata Pelajaran Bahasa Indonesia.

\begin{abstract}
Speaking skill is one of required skills in the realm of education. Bureau of Research and Development oh National Education Departement (2011) revealed the average grade of Bahasa Indonesia for high school its equal is at 7,12. On the other side, the average grade for English subject is at 7,52, Mathematics 7,30, and IPA 7,41. In order to improve the learning process, it needs a new model such as Think Pair Share in the readings. The phases in included in Think Pair Share are thinking, pairing, and sharing. This research conducted to reveals the speaking skills improvement of the student involved, i.e. the class XI SMK Garuda Nusantara, Demak term 2014/2015. Data obtained from this research would it analyzed using both qualitative and quantitative methods. Methods obtaining data would use tests, direct observations, questionnaire, interview, and documentation. The research design is employing two cycles. Each cycle involves planning, execution, observations, and reflection. The result of reflection would served as ground basic for the next cycle. The research concluded as it has observed in the percycle, there are only 8 students who gained grade 70 (21,62\%). But in the first cycle they are showinh significant improvement, e.g. 25 students (55,56\%). Thus there are improvement in as much as 33,94\%. After second cycle conducted, students who gained grade up to 70 raised in as much (93,33\%), and students who has not submitted the observations are as much as 3 students (06,67\%). It means that the results of thr second cycle has reached the KKM and fulfilling the completion standard in as much as $75 \%$. The research resulted in the fact tge applicationd of TPS model successfully improve the speaking skill of the students iIn the Bahasa Indonesia's subject.
\end{abstract}

Keyword: $\quad$ Cooperative learning model, Think Pair Share (TPS) to improve, speaking skill, Indonesia's subject. 


\section{PENDAHULUAN}

\section{Latar Belakang Masalah}

Bahasa memiliki empat keterampilan dasar, yang salah satu di antaranya adalah berbicara. Berbicara merupakan salah satu keterampilan berbahasa yang utama dan yang pertama kali dipelajari oleh manusia dalam hidupnya sebelum mempelajari keterampilan berbahasa lainnya.

Permasalahan yang dihadapi peserta didik dalam berbicara situasi dan kondisi yang tidak nyaman, penguasaan materi, dan penggunaan model pembelajaran. Menurut catatan panitia pusat, rata-rata nilai UN bahasa Indonesia tingkat sekolah menengah atas dan sederajat sebesar 7,12. Dengan nilai terendah 0,40 atau hanya benar dua butir soal dan nilai tertinggi 10,00. Nilai tersebut lebih rendah dari rata-rata mata pelajaran lainnya, yaitu bahasa Inggris sebesar 7,52, Matematika sebesar 7,30, dan IPA sebesar 7,41. Rendahnya nilai UN Bahasa Indonesia karena mata pelajaran ini dianggap mudah dan sepele oleh sebagian peserta didik.

Menurut Nurhadi (2005: 112) bahwa pembelajaran kooperatif adalah pendekatan pembelajaran yang berfokus pada penggunaan kelompok kecil peserta didik untuk bekerja sama dalam memaksimalkan kondisi belajar untuk mencapai tujuan belajar. Salah satu inovasi yang diharapkan dengan penerapan pembelajaran kooperatif Think Pair Share. Pelaksanaan metode Think Pair Share dibagi menjadi tiga tahap, yaitu thinking (berpikir), pairing (berpasangan), dan sharing (berbagi). Melalui proses ini, peserta didik dapat belajar dari pengalaman secara nyata sehingga keaktifan peserta didik dapat lebih meningkat.

\section{Rumusan Masalah}

Berdasarkan masalah yang telah teridentifikasi, rumusan masalahnya adalah sebagai berikut.

1. Apakah proses penerapan model pembelajaran kooperatif teknik TPS dalam pembelajaran keterampilan berbicara peserta didik kelas XI SMK Garuda Nusantara sudah efektif?

2. Bagaimanakah penerapan model pembelajaran kooperatif teknik TPS dalam pembelajaran keterampilan berbicara peserta didik kelas XI SMK Garuda Nusantara sudah efektif?

3. Bagaimanakah hasil penerapan model pembelajaran kooperatif teknik TPS dalam peningkatan pembelajaran keterampilan berbicara pada peserta didik kelas XI SMK Garuda Nusantara?

\section{Tujuan Penelitian}

Berdasarkan rumusan masalah tersebut, tujuan penelitian ini adalah sebagai berikut:

1. mendeskripsikan penerapan model pembelajaran kooperatif teknik TPS dalam pembelajaran keterampilan berbicara peserta didik kelas XI SMK Garuda Nusantara.

2. Mendeskripsikan langkah-langkah penerapan model pembelajaran kooperatif teknik TPS dalam pembelajaran keterampilan berbicara peserta didik kelas XI SMK Garuda Nusantara.

3. mendeskripsikan hasil penerapan model pembelajaran kooperatif teknik TPS dalam peningkatan pembelajaran keterampilan berbicara pada peserta didik kelas XI SMK Garuda Nusantara.

\section{Manfaat Penelitian}

Adapun manfaat penelitian yang dapat diperoleh dari penelitian ini, di antaranya adalah sebagai berikut.

1. Bagi Peneliti

Peneliti mendapatkan pengetahuan dan pengalaman berharga dari penelitian dan peneliti dapat terpacu untuk lebih kreatif dalam mengembangkan pembelajaran bahasa dan sastra Indonesia, khususnya berbicara.

2. Bagi Guru

Guru memperoleh wawasan tentang alternatif model pembelajaran kooperatif teknik Thing Pair Share.

3. Bagi Peserta Didik

Penggunaan metode ini diharapkan dapat membantu peserta didik untuk meningkatkan keterampilan berbicara, sehingga dapat mengembangkan potensi individualnya secara optimal.

4. Bagi Sekolah

Pihak sekolah dapat memperoleh informasi tentang kemampuan peserta 
didiknya dalam keterampilan berbicara dengan menggunakan model Thing Pair Share, sehingga dapat dijadikan landasan dalam meningkatkan kualitas pembelajaran bahasa.

\section{KAJIAN PUSTAKA}

\section{Pengertian Metode Pembelajaran}

Menurut Sudjana (2005:76) metode pembelajaran adalah metode pembelajaran ialah cara yang dipergunakan guru dalam mengadakan hubungan dengan peserta didik pada saat berlangsungnya pengajaran. Supriyadi (2008: 4.3) mengatakan bahwa metode adalah suatu cara yang teratur atau yang telah dipikirkan secara mendalam untuk digunakan dalam mencapai sesuatu.

\section{Pembelajaran Kooperatif}

Menurut Nurhadi (2005:112) bahwa pembelajaran kooperatif (Cooperatif Learning) adalah pendekatan pembelajaran yang berfokus pada penggunaan kelompok kecil peserta didik untuk bekerja sama dalam memaksimalkan kondisi belajar untuk mencapai tujuan belajar. Pembelajaran kooperatif merupakan salah satu revolusi dalam pembelajaran di kelas. Model pembelajaran kooperatif tidak sama dengan sekadar belajar kelompok.

Ada prinsip dasar pembelajaran kooperatif yang membedakannya dengan pembelajaran biasa. Lie (2008: 31) menyatakan bahwa untuk mencapai hasil yang maksimal, terdapat lima prinsip pembelajaran kooperatif yang harus diterapkan, yaitu saling ketergantungan positif, tanggung jawab perseorangan, tatap muka, komunikasi antaranggota, dan evaluasi proses kelompok.

\section{Metode Pembelajaran Kooperatif Think Pair Share}

Metode pembelajaran Think Pair Share merupakan metode sederhana, tetapi bermanfaat yang dikembangkan oleh Lyman dari Universitas Maryland (Slavin 2008: 257). Metode Pembelajaran ini menempatkan pendidik sebagai fasilitator bukan sebagai pemberi informasi. Pembelajaran Think Pair Share merupakan metode pembelajaran kooperatif. Pendekatan ini memberikan penekanan pada penggunaan struktur tertentu yang dirancang untuk mempengaruhi pola interaksi peserta didik. Lie (2008: 56) menyatakan bahwa teknik bertukar pasangan ini memberi peserta didik kesempatan untuk bekerja sama dengan orang lain. Teknik ini biasa digunakan pada mata pelajaran dan untuk semua tingkat usia anak didik.

Metode ini menekankan pada struktur khusus yang dirancang untuk mempengaruhi pola-pola interaksi peserta didik. Struktur ini menghendaki agar peserta didik bekerja sama, saling melengkapi dan saling bergantung dalam kelompok-kelompok kecil secara kooperatif. Metode Think Pair Share merupakan salah satu metode yang memiliki struktur dengan bertujuan untuk meningkatkan penguasaan akademik (Nurhadi 2005: 119). Dalam pelaksanaannya, ada beberapa tahapan pelaksanaan metode pembelajaran Think Pair Share, sebagaimana diuraikan berikut ini.

a. Tahap Pelaksanaan Metode Pembelajaran Think Pair Share

Metode pembelajaran Think Pair Share memiliki langkah-langkah yang ditetapkan secara eksplisit untuk memberi waktu lebih banyak untuk berfikir, menjawab, dan saling membantu satu sama lain bagi peserta didik. Sebagai contoh, guru baru saja menyajikan suatu topik atau peserta didik baru saja selesai membaca suatu tugas. Selanjutnya, guru meminta peserta didik untuk memikirkan permasalahan pada topik atau bacaan tersebut dengan serius.

Tahap-tahap dalam pembelajaran Think Pair Share menurut Lyman dalam Nurhadi (2005: 120) adalah thinking (berpikir), pairing (berpasangan), dan sharing (berbagi).

1. Thinking (berpikir) merupakan tahapan pada saat guru memberikan pertanyaan atau isu yang berhubungan dengan pelajaran, kemudian peserta didik diminta untuk memikirkan jawaban dari pertanyaan atau isu secara mandiri. Biasanya guru memberikan waktu satu menit untuk peserta didik berpikir mandiri.

2. Pairing (berpasangan) merupakan tahapan pada saat guru meminta peserta didik untuk berpasangan dengan peserta 
didik yang lain untuk mendiskusikan apa yang telah dipikirkan pada langkah pertama. Interaksi pada tahap ini diharapkan dapat menghasilkan jawaban bersama jika pertanyaan telah diajukan atau penyampaian ide bersama dan jika suatu pertanyaan khusus telah diidentifikasi. Biasanya guru memberikan waktu 4-5 menit untuk berpasangan.

3. Sharing (berbagi) merupakan tahapan pada saat guru meminta pasanganpasangan peserta didik tersebut untuk berbagi atau bekerja sama dengan kelas secara keseluruhan mengenai apa yang telah didiskusikan. Langkah ini dilakukan dengan cara bergantian pasangan demi pasangan dan dilanjutkan sampai beberapa peserta didik telah mendapatkan kesempatan untuk melaporkan, paling tidak, sekitar seperempat pasangan, tetapi disesuaikan dengan waktu yang tersedia. Pada langkah ini akan menjadi efektif apabila guru berkeliling kelas dari pasangan yang satu ke pasangan yang lain.

b. Kelebihan dan Kekurangan Metode Pembelajaran Think Pair Share

Tidak ada metode belajar yang sempurna yang dapat dilakukan dalam proses pembelajaran. Suatu metode belajar pasti mempunyai kelebihan maupun kekurangan. Kelebihan dari metode belajar dapat tercapai apabila ada tanggung jawab individual dari setiap anggota kelompok. Artinya, keberhasilan kelompok ditentukan oleh hasil belajar individual setiap anggota kelompok.

Selain itu, diperlukan adanya pengakuan kepada kelompok yang kinerjanya baik, sehingga anggota kelompok tersebut dapat melihat bahwa kerja sama untuk saling membantu teman dalam satu kelompok sangat penting. Kelemahan yang ada diharapkan dapat diminimalisasi dengan peran guru yang senantiasa meningkatkan motivasi peserta didik yang lemah agar dapat berperan aktif, meningkatkan tanggung jawab peserta didik untuk belajar bersama, dan membantu peserta didik yang mengalami kesulitan.

Lie (2008: 86) menyatakan bahwa kelebihan dan kekurangan kelompok berpasangan adalah sebagai berikut. Kelebihan kelom- pok berpasangan adalah sebagai berikut: (1) meningkatkan partisipasi peserta didik dalam pembelajaran, (2) cocok digunakan untuk tugas yang sederhana, (3) memberikan lebih banyak kesempatan untuk kontribusi masingmasing anggota kelompok, (4) mempermudah interaksi antar pasangan, dan (5) lebih mudah dan cepat dalam membentuk kelompoknya. Sementara itu, kekurangan kelompok berpasangan adalah sebagai berikut: (1) lebih banyak kelompok yang akan melapor dan perlu dimonitor, (2) lebih sedikit ide yang muncul, dan (3) jika ada masalah tidak ada penengah

\section{Karakteristik Keterampilan Berbicara}

Pengertian, tujuan, ragam berbicara, faktor penunjang keterampilan berbicara, dan ruang lingkup pembelajaran berbicara KTSP.

\section{Pengertian Berbicara}

Keterampilan berbahasa terdiri atas empat aspek, yaitu menyimak atau mendengarkan, berbicara, membaca, dan menulis. Peserta didik harus menguasai keempat aspek tersebut agar terampil berbahasa. Dengan demikian, pembelajaran keterampilan berbahasa di sekolah tidak hanya menekankan pada teori, tetapi peserta didik dituntut juga mampu menggunakan bahasa sebagaimana fungsinya, yaitu sebagai alat untuk berkomunikasi. Berbicara merupakan salah satu aspek keterampilan berbahasa yang bersifat produktif. Artinya, suatu kemampuan yang dimiliki seseorang untuk menyampaikan gagasan, pikiran atau perasaan sehingga gagasan-gagasan yang ada dalam pikiran pembicara dapat dipahami orang lain.

Berbicara berarti mengemukakan ide atau pesan lisan secara aktif melalui lambanglambang bunyi agar terjadi kegiatan komunikasi antara penutur dan mitra tutur. Memang, setiap orang dikodratkan untuk bisa berbicara atau berkomunikasi secara lisan, tetapi tidak semua memiliki keterampilan untuk berbicara secara baik dan benar. Oleh karena itu, pelajaran berbicara seharusnya mendapat perhatian dalam pengajaran keterampilan berbahasa di sekolah dasar.

Menurut Pageyasa (2005: 43) bahwa keterampilan berbicara adalah kemampuan mengungkapkan pendapat atau pikiran dan 
perasaan kepada seseorang atau sekelompok orang secara lisan baik berhadapan ataupun dengan jarak jauh. Dapat dikatakan bahwa berbicara merupakan suatu sistem tanda-tanda yang audible (dapat didengar) dan yang visible (kelihatan) yang memanfaatkan sejumlah otot tubuh manusia demi maksud dan tujuan gagasan atau ide-ide yang dikomunikasikan.

Berbicara merupakan suatu bentuk perilaku manusia yang memanfaatkan faktorfaktor fisik, psikologis, neurologis, semantik, dan linguistik. Sejalan dengan pendapat Pageyasa, Slamet (2007:12) menjelaskan bahwa berbicara adalah kegiatan mengekspresikan gagasan, perasaan, dan kehendak pembicara yang perlu diungkapkan kepada orang lain dalam bentuk ujaran. Kaitan antara pesan dan bahasa lisan sebagai media penyampaian sangat berat. Pesan yang diterima oleh pendengar tidaklah dalam wujud asli, tetapi dalam bentuk lain yakni bunyi bahasa. Pendengar kemudian mencoba mengalihkan pesan dalam bentuk bunyi bahasa itu menjadi bentuk semula.

Berbicara merupakan suatu kemampuan mengucapkan bunyi-bunyi artikulasi atau kata-kata untuk mengekspresikan, menyatakan atau menyampaikan pikiran, gagasan dan perasaan. Berbicara adalah suatu alat untuk mengkomunikasikan gagasan-gagasan yang disusun serta dikembangkan sesuai dengan kebutuhan-kebutuhan pendengar atau penyimak (Tarigan 2008: 16).

Berdasarkan beberapa pendapat tersebut disimpulkan bahwa berbicara itu tidak sekadar mengucapkan bunyi-bunyi atau kata-kata, melainkan juga suatu alat untuk mengkomunikasikan gagasan-gagasan yang disusun serta dikembangkan sesuai dengan kebutuhankebutuhan pendengar atau penyimak.

\section{Tujuan Berbicara}

Setiap kegiatan berbicara yang dilakukan manusia selalu mempunyai maksud dan tujuan. Menurut Tarigan (2008: 16) bahwa tujuan utama berbicara adalah untuk berkomunikasi. Agar dapat menyampaikan pikiran secara efektif, sebaiknya pembicara memahami segala sesuatu yang ingin dikomunikasikan. Dia harus mampu mengevaluasi efek komunikasinya terhadap para pendengarnya dan harus mengetahui prinsipprinsip yang mendasari segala situasi tiga maksud umum, yaitu (a) to inform (memberitahukan dan melaporkan), (b) to entertain (menjamu dalam pembicaraan), baik secara umum maupun perorangan. Pada dasarnya berbicara mempunyai menghibur, (c) to persuade (membujuk, mengajak, mendesak, dan meyakinkan).

Tim LBB SSC Intersolusi (2006:84) berpendapat bahwa tujuan berbicara bertujuan untuk (a) memberitahukan sesuatu kepada pendengar, (b) meyakinkan atau mempengaruhi pendengar, dan (c) menghibur pendengar. Pentingnya keterampilan berbicara atau bercerita dalam komunikasi juga diungkapkan oleh Supriyadi (2008: 178) bahwa apabila seseorang memiliki keterampilan berbicara yang baik akan memperoleh keuntungan sosial maupun profesional.

Keuntungan sosial berkaitan dengan kegiatan interaksi sosial antarindividu, sedangkan, keuntungan profesional diperoleh sewaktu menggunakan bahasa untuk membuat pertanyaan-pertanyaan, menyampaikan faktafakta dan pengetahuan, menjelaskan dan mendeskripsikan. Keterampilan berbahasa lisan tersebut memudahkan peserta didik berkomunikasi dan mengungkapkan ide atau gagasan kepada orang lain.

\section{Ragam Berbicara}

Ragam berbicara mencakupi pidato, diskusi, menyampaikan pengumuman, menyampaikan argumentasi, bercerita, musyawarah, dan wawancara.

a. Pidato

Pidato adalah berbicara di depan umum. Jika pidato tadi bersifat ilmiah disebut ceramah. Teks pidato adalah bahan tertulis yang digunakan untuk berpidato/ berceramah. Apabila teks tadi dibuat sendiri oleh pembicara disebut naskah pidato.

\section{b. Diskusi}

Diskusi berarti memberikan jawaban atas pertanyaan atau pembicaraaan serius tentang suatu masalah objektif. Dalam proses ini orang mengemukakan titik tolak pendapatnya, menjelaskan alasan, dan hubungan antar masalah. Dalam arti sempit, diskusi berarti 
tukar-menukar pikiran yang terjadi di dalam kelompok kecil atau kelompok besar.

\section{c. Menyampaikan Pengumuman}

Menyampaikan pengumuman berarti menyampaikan sesuatu hal yang perlu diketahui oleh khalayak ramai. Kegiatan ini diwujudkan dalam bentuk pidato. Ciri-ciri yang harus diperhatikan dalam membaca pengumuman diantaranya, yaitu volume suara harus lebih keras, intonasi yang tepat, dan gaya penampilan yang menarik.

\section{d. Menyampaikan Argumentasi}

Salah satu proses komunikasi untuk menyampaikan argumentasi karena harus mepertahankan pendapat, yaitu debat. Setiap pihak yang berdebat akan mengajukan argumentasi dengan memberikan alasan tertentu agar pihak lawan atau peserta menjadi yakin dan berpihak serta setuju terhadap pendapatpendapatnya (Laksono 2008:3).

\section{e. Bercerita}

Melalui bercerita dapat terjalin hubungan yang akrab. Selain itu, manfaat bercerita diantaranya, yaitu memberikan hiburan, mengajarkan kebenaran, dan memberikan keteladanan. Seorang pendongeng dapat berhasil dengan baik apabila ia dapat menghidupkan cerita. Artinya, dalam hal ini pendongeng harus dapat membangkitkan daya imajinasi anak. Untuk itu, biasanya pendongeng mempersiapkan diri dengan cara memahami pendengar, menguasai materi cerita, menguasai oleh suara, menguasai berbagai macam karakter, luwes dalam berolah tubuh, dan menjaga daya tahan tubuh.

\section{a. Musyawarah}

Musyawarah mengandung arti perundingan, yaitu membicarakan sesuatu supaya mencapai kata sepakat. Mencapai kata sepakat tentu tidak mudah karena setiap orang mempunyai kepentingan pribadi. Dalam suatu musyawarah yang penting adalah kepentingan orang banyak, setiap orang mengesampingkan kepentingan pribadi demi kepentingan umum.

\footnotetext{
b. Wawancara

Wawancara merupakan salah satu keterampilan berbicara yang digunakan sebagai
}

metode pengumpulan berita. Pelaksanaannya bisa dilakukan secara langsung bertatap muka dengan orang yang diwawancarai atau secara tidak langsung, seperti melalui telepon, internet, atau surat.

\section{Faktor Penunjang Keterampilan Berbicara}

Berbicara atau kegiatan komunikasi lisan merupakan kegiatan individu dalam usaha menyampaikan pesan secara lisan kepada sekelompok orang, yang disebut juga audience atau majelis. Supaya tujuan pembicaraan atau pesan dapat sampai kepada audience dengan baik, perlu diperhatikan beberapa faktor yang dapat menunjang keefektifan berbicara. Kegiatan berbicara juga memerlukan hal-hal di luar kemampuan berbahasa dan ilmu pengetahuan. Pada saat berbicara, diperlukan (a) penguasaan bahasa, (b) bahasa, (c) keberanian dan ketenangan, (d) kesanggupan menyampaikan ide dengan lancar dan teratur. Faktor penunjang pada kegiatan berbicara sebagai berikut. Faktor kebahasaan, mencakupi (a) ketepatan ucapan, (b) penempatan tekanan nada, sendi atau durasi yang sesuai, (c) pilihan kata, (d) ketepatan penggunaan kalimat serta tata bahasanya, (e) ketepatan sasaran pembicaraan. Sementara itu, faktor nonkebahasaan, mencakupi (a) sikap yang wajar, tenang dan tidak kaku, (b) pendangan harus diarahkan ke lawan bicara, (c) kesediaan menghargai orang lain, (d) gerak-gerik dan mimik yang tepat, (e) kenyaringan suara, (f) kelancaran, (g) relevansi, penalaran, $(\mathrm{h})$ penguasaan topik

Berdasarkan uraian tersebut disimpulkan bahwa faktor-faktor yang mempengaruhi kegiatan berbicara adalah faktor urutan kebahasaan (linguitik) dan nonkebahasaan (nonlinguistik).

\section{METODE PENELITIAN}

\section{Subjek Penelitian}

Subjek penelitian yang dilakukan peneliti adalah peserta didik SMK Garuda Nusantara, Demak yang berjumlah 40 peserta didik.

\section{Tempat dan Waktu Penelitian}

Penelitian ini dilaksanakan di kelas XI di SMK Garuda Nusantara, Kecamatan Kuripan, 
Kabupaten Demak Tahun Pelajaran 2015/ 2016. Penelitian telah dilaksanakan selama enam bulan, sejak April-September 2015.

\section{Data Penelitian}

Data yang dikumpulkan dalam penelitian ini mencakupi data informasi tentang keadaan peserta didik dilihat dari aspek kualitatif dan kuantitatif.

\section{Metode Pengumpulan Data}

Metode pengumpulan data yang dipakai dalam penelitian ini adalah wawancara, tes, kuesioner, dan dokumentasi. Kisi-kisi kuesinoer dapat dilihat pada tabel 1 berikut.

Tabel 1 Kisi-Kisi Angket

\begin{tabular}{|l|c|c|}
\hline \multicolumn{1}{|c|}{ Indikator } & Butir & Jumlah \\
\hline $\begin{array}{l}\text { Keberhasilan } \\
\text { pembelajaran dengan } \\
\text { metode TPS }\end{array}$ & $1,2,3,4,5$ & 5 \\
\hline $\begin{array}{l}\text { Interaksi belajar } \\
\text { peserta didik dalam } \\
\text { kelompok }\end{array}$ & 6,7 & 2 \\
\hline Penilaian peserta didik & 8 & 1 \\
\hline $\begin{array}{l}\text { Penilaian peserta didik } \\
\text { terhadap metode TPS }\end{array}$ & 9,10 & 2 \\
\hline
\end{tabular}

\section{Desain Prosedur Penelitian}

Desain penelitian tindakan kelas ini terdiri atas 2 siklus. Setiap siklus terdapat empat tahap, sebagaimana yang dikemukakan Arikunto (2006:16), yaitu planning (perencanaan), acting (pelaksanaan), observing (pengamatan), dan reflecting (refleksi).

\section{Teknik Analisis Data}

Teknik analisis data dilakukan secara kuantitatif dan kualitatif.

\section{HASIL PENELITIAN DAN PEMBAHASAN}

\section{Hasil Penelitian}

Hasil tes praiklus, siklus I, dan siklus II dengan materi yang berbeda.

\section{Penerapan Model Pembelajaran Kooperatif Teknik TPS Pembelajaran}

\section{Keterampilan Berbicara Peserta Didik Kelas XI SMK Garuda Nusantara}

Berdasarkan hasil penelitian prasiklus, dari 37 siswa hanya 8 peserta didik yang memperoleh nilai tuntas dengan persentase sebesar $21,62 \%$, sedangkan 29 peserta didik belum tuntas dengan persentase sebesar $78,38 \%$. Dengan demikian pembelajaran dianggap belum tuntas.

\section{Deskripsi Hasil Penerapan Model Pembelajaran Kooperatif Teknik TPS Pembelajaran Keterampilan Berbicara Peserta Didik Kelas XI SMK Garuda Nusantara, Demak}

\section{Siklus I}

Dari data, diketahui bahwa nilai rata-rata peserta didik sebesar 70,67 dengan jumlah peserta didik yang belum tuntas sebanyak 20 orang dengan persentase sebesar 44,44\%, sedangkan peserta didik yang sudah tuntas sebanyak 25 orang dengan persentase $55,56 \%$.

\section{Siklus II}

Dari data dapat diketahui bahwa nilai rata-rata peserta didik adalah 78,22 dengan jumlah peserta didik yang belum tuntas sebanyak 3 orang $(06,67 \%)$, sedangkan peserta didik yang sudah tuntas sebanyak 42 orang (93,33\%). Dengan demikian, dapat disimpulkan bahwa perbaikan pembelajaran siklus II tentang penyampaian parafrasa yang telah dibuat dengan media puisi meningkat, yaitu pada siklus I 55,56\% menjadi $93,33 \%$. Peningkatannya sebesar $37,78 \%$.

\section{Pembahasan Hasil Penelitian Perbaikan Pembelajaran}

Hasil pembahasan penelitian tindakan kelas ini dilaksanakan dengan dua tahap, yaitu siklus I dan siklus II.

\section{Siklus I}

Hasil pengamatan, analisis hasil, lembar perbaikan, dan pengayakan terlampir pada siklus I. Belum tuntasnya nilai (70) dan target $(75 \%)$ yang peneliti inginkan, peneliti melakukan penelitian siklus II.

\section{Siklus II}


Tabel 2

Nilai rekapitulasi hasil perolehan nilai tes formatif prasiklus, siklus 1, dan siklus II.

\begin{tabular}{|c|c|c|}
\hline Siklus & Tuntas & Belum Tuntas \\
\hline Prasiklus & $21,62 \%$ & $78,38 \%$ \\
\hline Siklus 1 & $55,56 \%$ & $44,44 \%$ \\
\hline Siklus 2 & $93,33 \%$ & $6,67 \%$ \\
\hline
\end{tabular}

\section{SIMPULAN DAN SARAN}

\section{Simpulan}

Berdasarkan hasil perbaikan pembelajaran yang telah dilaksanakan pada peserta didik kelas XII SMK Garuda Nusantara, Demak Tahun Ajaran 2015/2016, disimpulkan bahwa penggunaan media puisi dapat meningkatkan kemampuan berbicara peserta didik menyampaikan laporan dan parafrasa dalam konteks tugas.

\section{Saran}

Berdasarkan simpulan hasil penelitian pembelajaran tindakan kelas, peneliti menyarankan hal-hal sebagai berikut.

(a) Guru hendaknya mampu menggunakan metode maupun media pembelajaran yang tepat sesuai dengan materi pembelajaran, khususnya bahasa Indonesia.

(b) Guru hendaknya berperan sebagai fasilitator dan motivator yang mampu membagi pengalaman belajar yang memungkinkan peserta didik bertanggung jawab dalam melakukan proses pembelajaran.

(c) Guru hendaknya menggunakan media antologi puisi dalam meningkatkan kemampuan peserta didik berkompetensi membaca.

(d) Dalam proses pembelajaran, diharapkan peserta didik lebih aktif dan antusias demi peningkatan hasil evaluasi belajarnya.

(e) Peserta didik belajar untuk fokus dan mengontrol diri agar tercipta iklim yang kondusif selama pembelajaran, sehingga berimbas pada peningkatan nilai prestasi

\section{DAFTAR PUSTAKA}

Anita Lie. 2008. Cooperative Learning. Jakarta : Grasindo.

Arikunto, S., Suhardjono, dan Supardi. 2007. Penelitian Tindakan Kelas. Jakarta : Bumi Aksa

Djamarah, S.B dan Zain, A. 2010. Strategi Belajar Mengajar. Jakarta: Rineka Cipta.

Garfield, J. 2008. "Teaching Statistics Using Small-Group Cooperative Learning”. Journal of Statistic Education. 1:1524, (http://CLand Reading Aloud.htm, diakses tanggal 12 Juli 2009).

Laksono, Kisyanti. 2008. Berbicara. Jakarta: Direktorat Pendidikan Lanjutan Pertama Direktorat Jenderal Pendidikan Dasar dan Menengah Departemen Pendidikan Nasional.

Nur, Muhammad. 2005. Pembelajaran Kooperatif. Departemen Pendidikan Nasional Direktorat Pendidikan Dasar dan Menengah Lembaga Penjamin Mutu Jawa Timur.

Sutikno, Sobri M. 2009. Belajar dan Pemebelajaran. Bandung: Prospect.

Pageyasa, Wayan. 2004. Peningkatan Kemampuan Berbicara. Jakarta: Balai Pustaka.

Slamet dan Amir. 2007. Peningkatan Keterampilan Berbahasa Indonesia: Bahasa Lisan dan Bahasa Tertulis. Surakarta: Universitas Sebelas Maret.

Slavin, E. Robert. 2008. Coorporative Learnung: Teori, Riset, dam Praktik. Bandung: Nusa Media.

Supriyadi. 2008. Strategi Belajar Mengajar. Yogyakarta: Cakrawala Ilmu.

Tarigan, Henry Guntur. 2007. Berbicara sebagai Suatu Keterampilan Berbahasa. Bandung: Angkasa

Tim LBB SSCIntersolusi. 2006. Bahasa Indonesia SMA 3. Yogyakarta: SSCIntersolusi. 